Summer 2004

\title{
From a State-Centered Approach to Transnational Openness: Adapting the Hague Convention with Contemporary Human Rights Standards as Codified in the Convention of the Rights of the Child
}

\author{
Allison M. Scott \\ Indiana University School of Law
}

Follow this and additional works at: https://www.repository.law.indiana.edu/ijgls

Part of the Family Law Commons, Human Rights Law Commons, and the International Law Commons

\section{Recommended Citation}

Scott, Allison M. (2004) "From a State-Centered Approach to Transnational Openness: Adapting the Hague Convention with Contemporary Human Rights Standards as Codified in the Convention of the Rights of the Child," Indiana Journal of Global Legal Studies: Vol. 11 : Iss. 2 , Article 7.

Available at: https://www.repository.law.indiana.edu/ijgls/vol11/iss2/7

This Note is brought to you for free and open access by the Law School Journals at Digital Repository @ Maurer Law. It has been accepted for inclusion in Indiana Journal of Global Legal Studies by an authorized editor of Digital Repository @ Maurer Law. For more information, please contactrvaughan@indiana.edu.

\section{$\Psi$}

JEROME HALL LAW LIBRARY

INDIANA UNIVERSITY

Maurer School of Law
Blooming ton 


\title{
From a State-Centered Approach to Transnational Openness: Adapting the Hague Convention with Contemporary Human Rights Standards as Codified in the Convention on the Rights of the Child
}

\author{
Allison M. Scotr*
}

\section{INTRODUCTION}

Parental kidnapping is an increasing problem throughout the world and the social consequences of globalization have made international child abductions more frequent. In the United States alone, the Department of Justice states that 354,100 children are reported to have been abducted by a family member in a single year. ${ }^{1}$ Estimates indicate that one in five parental kidnappings involves a child being taken across international borders. ${ }^{2}$ The United Kingdom states that in the last three years there has been a " 58 percent increase in the number of international parental child abductions." In 2000, the National Center for Missing and Exploited Children, which handles all U.S. international child abduction cases, reported 1,697 international abductions, up 66.7 percent over 1999. ${ }^{4}$

The increase of international child abductions has been attributed to the increasing access of international travel and rising divorce rates. ${ }^{5}$ International ab-

*J.D. Candidate, 2004, Indiana University School of Law-Bloomington; B.S. Psychology, 2001, University of Illinois-Urbana-Champaign. The author wishes to express her immense gratitude to Professor Jost Delbrück for his assistance and instrumental guidance in developing this Note. The author would also like to thank her family for their continuing love, encouragement, and support.

1. See Nigel Lowe, National Ctr. For Missing and Exploited Children, International Forum on Parental Child Abduction: Hague Convention Action Agenda (1999) (citing D. Finkelhor et al., United States Department of Justice, Fact Sheet on Missing Children: National Incidences Studies of Missing, Agducted, Runaway, and Thrownaway Children 1 (1990)).

2. See Rebecaa Hegar, Parental Kidnapping Across International Borders, 34 InT'L Soc. Work 353 (1991).

3. See Lowe, supra note 1 , at 2.

4. See National Ctr. For Missing and Exploited Children, 2000 Annual Report.

5. See Marcia M. Reisman, Comment, Where to Decide the "Best Interests" of Elian Gonzales: The Law of Abduction and International Custody Disputes, 31 U. Miami Inter-Am. L.. Rev. 323, 324 (2000). 
ductions are more traumatic for both the child and the parent than domestic abductions. ${ }^{6}$ This is because "sheer distance, language barriers, and differences in cultural, legal, and economic systems intensify the trauma felt by the aggrieved parent as well as the child." "In addition, the child's separation and complete isolation from his or her former life greatly increases the trauma he or she will endure. ${ }^{8}$ Regardless of the cause of the increase in child abductions across international borders, something needs to be done to stop this problem.

\section{A. The State-Centered Approach of the Hague Convention}

In order to protect children from international abductions, the Hague Convention on the Civil Aspects of International Child Abduction was established in $1980 .{ }^{9}$ The Hague Convention has been ratified by numerous countries. ${ }^{10}$ However, the Hague Convention is not working uniformly and it has numerous

6. See Antoinette Passanante, Note, International Parental Kidnapping: The Call for an Increased Federal Response, 34 Colum. J. Transnat'l L. 677, 678 (1996).

7. Id. at 678-79.

8. See Susan Kreston, Prosecuting International Parental Kidnapping, 15 Notre Dame J. L. Ethics \& Pub. Pol'y 533, 534 (2001).

9. Hague Conference on Private International Law: Hague Convention on the Civil Aspects of International Child Abduction, Nov. 24, 1980, 19 I.L.M. 1501 (1980) [hereinafter Hague Convention]. The Hague Convention was the final act of the Fourteenth Session of the Hague Conference on Private International Law. Delegates from the following nations were present: Argentina, Australia, Austria, Belgium, Canada, Czechoslovakia, Denmark, the Arab Republic of Egypt, Finland, France, the Federal Republic of Germany, Greece, Ireland, Israel, Italy, Japan, Yugoslavia, Luxembourg, the Netherlands, Norway, Portugal, Spain, Surinam, Sweden, Switzerland, Turkey, the United Kingdom of Great Britain and Northern Ireland, the United States of America, and Venezuela; also, representatives from the Governments of Brazil, the Holy See, Hungary, Monaco, Morocco, the Union of Soviet Socialist Republics, and Uruguay participated by invitation or as Observer. Id.

10. Lowe, supra note 1, at 4. The following countries are Contracting States under The Hague Convention: Argentina, Australia, Austria, the Bahamas, Belarus, Belgium, Belize, Bosnia and Herzegovina, Brazil, Burkina Faso, Canada, Chile, China (Hong Kong Special Administrative Region only), Colombia, Costa Rica, Croatia, Cyprus, Czech Republic, Denmark, Ecuador, Fiji, Finland, the Former Yugoslav Republic of Macedonia, France, Georgia, Germany, Greece, Honduras, Hungary, Iceland, Ireland, Israel, Italy, Luxembourg, Malta, Mauritius, Mexico, Moldova, Monaco, Netherlands, New Zealand, Norway, Panama, Paraguay, Poland, Portugal, Romania, Saint Kitts and Nevis, Slovakia, Slovenia, South Africa, Spain, Sweden, Switzerland, Turkey, Turkmenistan, United Kingdom of Great Britain and Northern Ireland, United States of America, Uruguay, Uzbekistan, Venezuela, and Zimbabwe. See id. at 21. 
weaknesses that allow many cases to go unresolved. ${ }^{11}$ Problems with the Hague Convention include noncompliance issues and lack of enforceability; procedural slowness; excessive recourse to exceptions; lack of legal aid for victim families; and lack of applicability in a large number of countries that are not yet parties to the Convention. ${ }^{12}$ The Hague Convention primarily addresses matters of jurisdiction and "does little or nothing to promote the rights of children." 13 This Convention is very state-centered ${ }^{14}$ because it allows the judicial system of each participating country to exercise great discretion when interpreting the language of the Convention. ${ }^{15}$ The use of a state-centered approach by the Hague Convention provides less protection to children because a human rights universal, transnational standard is not being enforced.

\section{B. Transnational Openness of the Convention on the Rights of the Child}

Conversely, the Convention on the Rights of the Child moves away from a state-centered approach toward a transnational, ${ }^{16}$ global standard. This Convention sets forth specific enumerated rights for children ${ }^{17}$ and has been almost universally adopted. ${ }^{18}$ The goal of this Convention is to "emphasize the child's

\section{See id. at 7 .}

12. Id. Parties that are not yet Contracting States include large parts of Africa, China (with the exception of Hong Kong), India, most Islamic countries, Japan and most other countries in the Far East, Russia and most of the former Soviet Union. Id. at 4.

13. June Starr, The Global Battlefield: Culture and International Child Custody Disputes at Century's End, 15 ARIz. J. InT'L \& Comp. L 791, 832 (1998).

14. See Jost Delbrück, Prospects for a "World (Internal) Law?": Legal Developments in a Changing International System, 9 IND. J. Global Leg. STUd. 401 (2002) (giving an explanation of how statecentered international laws are changing due to globalization).

15. See Courtney E. Hoben, The Hague Convention on International Parental Kidnapping: Closing the Article 13(b) Loophole, 5 J. Int'L Legal Stud. 271, 280-83 (1999).

16. Delbrück, supra note 14, at 421 (defining globalization as "a process of denationalization of the legal interactions in the international system" including those between private actors).

17. Resolution Adopted by the General Assembly, Convention on the Rights of the Child, Nov. 20, 1989, 28 I.L.M 1448, 1456 [hereinafter Convention on the Rights of the Child].

18. The Child's Right Convention has been ratified by 192 countries and only two countries have not ratified, the United States of America and Somalia. See UNICEF, The Convention on the Rights of Children, at http://www.unicef.org/crd/crc.htm [hereinafter UNICEF]. The United States has signaled its intention to ratify by formally signing the Child's Rights Convention and currently it is the "only industrialized country in the world and one of only two United Nations member States that have failed to make this legal commitment to children." Somalia is presently without a recognized government. Id. 
best interests in all actions concerning him or her, and these best interests are considered in the context of the child's family ties; continuity in upbringing; and ethnic, religious, cultural, and linguistic background." 19 This Convention overrides the domestic laws of each country and aims to preserve traditionalist, socialist structures, while promoting the human rights of children, even against these domestic laws. Thus, this Convention reaches past the domestic legal order, regardless of citizenship and thereby takes a non-state-centered approach. ${ }^{20}$

\section{Adopting a Transnational Approach}

In order to thoroughly protect children, the state-centered approach of the Hague Convention should be modified to include many of the transnational standards set forth in the Convention on the Rights of the Child. These two major conventions, each with a considerable to extraordinary level of acceptance by the international community of States, overlap in terms of children's rights. The children's rights provisions of the Hague Convention are not principally incompatible with the children's rights provisions of the Convention on the Rights of the Child; they are simply narrower or provide less protection to children. Since most State Parties are bound by both conventions, they are under an obligation to comply with both treaties. ${ }^{21}$ Thus, the Hague Convention needs to be interpreted more broadly in favor of the human rights protection standards set forth in the Convention on the Rights of the Child.

By interpreting the Hague Convention more broadly using the Convention on the Rights of the Child, the force of the global human rights movement overrides the state-centered approach of the Hague Convention, which gives priority to the authority of domestic courts in determining the fate of the children involved. ${ }^{22}$ If the Hague Convention complies with the Convention on the Rights of

19. See Cara L. Finan, Convention on the Rights of the Child: A Potentially Effective Remedy in Cases of International Child Abduction, 34 Santa Clara L. Rev. 1007, 1019-20 (1994) (citing Child's Right Convention, arts. 3, 9, 17-18, 20-21, 40).

20. See generally Delbrück, supra note 14.

21. Most of the State Parties are bound by both conventions; therefore, if the two treaties are partially incompatible, then an amendment to the earlier treaty, the Hague Convention, is the only way to adopt it to the later treaty, the Convention on the Rights of the Child.

22. See generally Brian S. Kenworthy, The Un-Common Law: Emerging Differences Between the United States and the United Kingdom on the Children's Rights Aspects of the Hague Convention on International Child Abduction, 12 Ind. INT'L \& Comp. L. Rev. 329, 337-38 (2002) (stating that the drafters of the Hague Convention wanted to allow all courts some discretion). 
the Child, the Hague Convention will open to transnational scrutiny decisions of domestic courts. Also, adopting the Convention on the Rights of the Child in applying the Hague Convention implies the recognition of the status of the children as subjects of international law, a result that is clearly in line with the general observation that globalization impacts the structure of the international system by diversifying the number of legally recognized actors. ${ }^{23}$ This impact is not only of doctrinal interest, but has very practical consequences for those affected by international abductions. Therefore, allowing the Hague Convention to adopt the transnational, human rights protection standard set forth in the Convention on the Rights of the Child, will enable the Hague Convention to reach its greatest potential. The Hague Convention will not only serve as a disincentive for individuals to commit international child abductions, because of the closer scrutiny resulting from international control, but it will also become a transnational and global document that strongly promotes human rights. ${ }^{24}$

This Note scrutinizes current methods being used to protect children, particularly taking into account the differences between the state-centered approach of the Hague Convention and the transnational approach of the Convention on the Rights of the Child. Part II examines the premises behind the Hague Convention, the requirements for its application, the exceptions for its application, and its overall effectiveness in fighting international child abductions. Part III describes the purpose and principles of the Convention on the Rights of the Child. Part IV will examine the discrepancies between the Hague Convention and the Convention on the Rights of the Child and how these discrepancies should be resolved so that the best interest of the child is always and consistently in the forefront. Part V concludes that the Hague Convention must adopt the transnational and global principles from the Convention on the Rights of the Child, thereby allowing the Hague Convention to not only be a remedy for international child abductions, but also allowing the Hague Convention to serve as a human rights document.

23. Delbrück, supra note 14, at 406 (describing how "the foundation of international organizations constituted a change of the structure of the international system" and how this change diversified the type of actors "participating in the transactions in the international system").

24. See Finan, supra note 19, at 1038 (stating that "[t]he world stands to gain a great deal by treating international child abductions as human rights violations.") 


\section{The Hague Convention on the Civil Aspects of International Child Abduction}

In the fall of 1980 , the international community met at The Hague to address the increasing problem of parental child abduction. ${ }^{25}$ The Hague Convention's purpose is to prevent international child abductions and to secure the prompt return of children to their habitual residence. ${ }^{26}$ The "overarching policy of the Convention [is] the creation of a system of close cooperation among judicial and administrative authorities of the contracting nations to prevent the international removal of children from their habitual residence."27 This Convention attempts to employ a novel approach by focusing on methods of fostering collaboration among the central authorities of each country instead of attempting to promote the enforcement and recognition of foreign decisions. ${ }^{28}$ In order to achieve the tasks of the Hague Convention, each country who is a signatory, deemed a Contracting State, must set up a "Central Authority." ${ }^{29}$ The

25. See Hoben, supra note 15, at 273. On October 24, 1980, the Hague Convention was adopted. Id. at 273-74.

26. Hague Convention, supra note 9 , art. 1 . The Hague Convention provides a purely civil remedy as opposed to a criminal remedy. See Passanante, supra note 6, at 690 . The drafters chose to address civil aspects of abduction mainly because criminal sanctions are generally inefficient in deterring international child abductions. Id.

27. See Jan Rewers McMillan, Current International and Domestic Issues Affecting Children: Getting Them Back: The Disappointed Reality of Return Orders Under the Hague Convention on the Civil Aspects of International Child Abduction, 14 J. Am. Acad. MatrIM. Law. 99, 101 (1997) (citing Eliza Perez-Vera, Explanatory Report, Hague Convention on Private International Law, 3 Acts and Documents of the Fourteenth Session para. 35 (1982)).

28. Finan, supra note 19, at 1013 (citing Lawrence N. Stotter, History to the Hague Convention, in Am. Bar Ass'n, International Child Abductions: A Guide to Applying the i 988 Hague Convention, with Forms 8 (Gloria F. DeHart ed., 1989)). Under this Convention, courts are not allowed to investigate the merits of the case. Lowe, supra note 1 , at 4 . Thus, courts do not and should not decide which parent should look after the child. Id. This responsibility is for the Court of the habitual state in which the child is a resident. Id. Article 16 supports this contention by stating:

After receiving notice of a wrongful removal or retention of a child ... the judicial or administrative authorities of the Contracting State to which the child has been removed or in which it has been retained shall not decide on the merits of rights of custody until it has been determined that the child is not to be returned under this Convention.

Hague Convention, supra note 9, art. 16, at 1503.

29. Hague Convention, supra note 9, arts. $6 \& 7$, at 1501-02. Under Article 6, each contract state is required to "designate a Central Authority to discharge the duties which are imposed by the 
parent-abductor is required to return the child to his or her habitual residence so that the issues disputed between the parents can be resolved. ${ }^{30}$

\section{A. Requirements for the Application of the Hague Convention}

In order for the Hague Convention to apply, the child must be younger than the age of sixteen, a habitual resident in one of the Contracting States, and the child must have been wrongfully removed to or retained in another Contracting State. ${ }^{31}$ Under this Convention, "wrongful" is defined as a removal or retention that breaches a right of custody under the laws of the state where the child was a habitual resident immediately before the removal. ${ }^{32}$ Wrongful removal occurs when a child is taken to an international frontier without permission of a parent or guardian who has custody rights. Wrongful retention takes place when a child is kept in a country longer than the agreed-upon period. ${ }^{33}$ Therefore, if the Hague Convention is going to apply, the child must be a habitual resident of a Contracting State and must have been wrongfully taken to a Contracting State. ${ }^{34}$ Furthermore, Article 35 states that the Convention will only apply between

Convention upon such authorities." Id. at 1501. Under Article 7, the Central Authorities are to "co-operate with each other and promote co-operation amongst the competent authorities in their respective states to secure the prompt return of children" and in particular they are required to take appropriate measures in discovering the child's whereabouts, securing the child's safe return, and providing legal aid when required. Id. at 1502.

30. Lowe, supra note 1 , at 4.

31. Hague Convention, supra note 9, arts. $3 \& 4$, at 1501. The Hague Convention states that it ceases "to apply when the child attains the age of 16 years." Id. at 1501. Regardless of a child's status, the Convention will cease to apply when the child obtains the age of 16. See also Finan, supra note 19 , at 1014 .

32. Hague Convention, supra note 9, art. 3, at 1501. Article 3 states:

[T] he removal or the retention of a child is to be considered wrongful where $-\mathbf{a}$. it is in breach of rights of custody attributed to a person, an institution or any other body, either jointly or alone, under the law of the State in which the child was habitually resident immediately before the removal or retention; and $b$. at the time of removal or retention those rights were actually exercised, either jointly or alone, or would have been so exercised but for the removal or retention.

Habitual residence "refers to the place where the child has his or her 'home'." Lowe, supra note 1, at 11 .

33. Lowe, supra note 1 , at 3.

34. Finan, supra note 19, at 1014. 
Contracting States when wrongful removals or retentions occurred after the Hague Convention has been entered into force in those States. ${ }^{35}$

A custody order does not have to be in effect for a parent to seek the return of an abducted child under the Hague Convention. ${ }^{36}$ Under Article 17, a Contracting State cannot base a decision not to return a child solely on a court order granting the wrongdoer custody. ${ }^{37}$ This ensures that the Hague Convention will "take precedence over decrees in favor of abductors before the court to which the abductor applies has notice of the wrongful removal or retention." ${ }^{38}$ Based on this requirement, the abductor is not able to avoid the requirements of the Convention by enforcing a custody order that was in place in another country or by attempting to acquire a custody order for the abducted child in the new country. ${ }^{39}$ The child plays a passive role in this situation. As such, the person who exercised custody rights before the abduction, or the person who would have exercised custody rights but for the abduction, must invoke the Hague Convention. ${ }^{40}$

If these requirements are met and the request for an order requiring the return of the child is brought quickly, ${ }^{41}$ the court of the Contracting State to which the child was taken must order a return "forthwith," unless the case falls under one of the Hague Convention exceptions. ${ }^{42}$

35. Id. at 1014-15. See also Hague Convention, supra note 9, at 1504.

36. Finan, supra note 19, at 1015.

37. Id. at 1015. Article 17 states:

The sole fact that a decision relating to custody has been given in or is entitled to recognition in the requested State shall not be a ground for refusing to return a child under this Convention, but the judicial or administrative authorities of the requested State may take account of the reasons for that decision in applying this Convention.

Hague Convention, supra note 9, at 1503.

38. Finan, supra note 19, at 1015.

39. Id. at 1015 .

40. Id. at 1014-15.

41. Article 12 states:

Where a child has been wrongfully removed or retained ... and, at the date of the commencement of the proceedings before the judicial or administrative authority of the Contracting State where the child is, a period of less than one year has elapsed from the date of the wrongful removal or retention, the authority concerned shall order the return of the child forthwith.

Hague Convention, supra note 9, at 1502.

42. See Lowe, supra note 1 , at 3. 


\section{B. Exceptions to the Requirement to Return a Child Under the Hague Convention}

There are six exceptions to the Hague Convention, anyone of which if met, allow a Contracting State the right to refuse to order the return of a child.$^{43}$ The exceptions apply when the custodial parent consented or acquiesced to the removal or retention; the custodial parent failed to exercise his/her custodial rights; the child is settled into his/her new environment; the return is not permitted by the requested nation's fundamental principles regarding human rights and fundamental freedoms; the return poses a "grave risk" of exposing the child to physical or psychological harm or an intolerable situation; or when the child objects to returning and is old enough and mature enough to make such objection. ${ }^{4+}$

These exceptions were not intended to be easily met; yet, even when a party meets the standards, the court still has the authority to order a child to be returned. ${ }^{45}$ Under Article 18, the judicial or administrative authority always has the right to order the return of a child at any time. ${ }^{46}$ Thus, the general rule is that a child who was wrongfully removed should be returned to his or her habitual residence. ${ }^{47}$

\section{Custodial Parent Exceptions}

Some of the exceptions are applicable because they negate a specific requirement of the Act, such as the wrongful removal of the child. This happens when the custodial parent acquiesces or consents to the removal or retention. ${ }^{48}$ Thus, without the requirement of a wrongful removal, the "applicability of the Hague Convention is directly at issue, and in such circumstances, courts are not mandated by the Article 12 duty to order the return of the child." 49 Also, the custodial parent must establish that he or she had custodial rights and that he or she was also exercising those custodial rights. ${ }^{50}$ Again, this is linked to the issue of

43. See Hague Convention, supra note 9 , arts. 3b, 12, 13, 20, at 1501-03.

44. Kenworthy, supra note 22, at 334-35; Hague Convention, supra note 9, art. 3b, 12, 13, 20, at $1501-03$.

45. Lowe, supra note 1 , at 4.

46. Hague Convention, supra note 9, at 1503.

47. See Lowe, supra note 1 , at 4.

48. Hague Convention, supra note 9, art. 13a, at 1502.

49. Kenworthy, supra note 22, at 335.

50. Id. Article $3 \mathrm{~b}$ states that removal is wrongful if custodial "rights were actually exercised, either jointly or alone, or would have been so exercised but for the removal or retention." Hague Convention, supra note 9 , at 1501. 
wrongful removal and the Convention presumes that a person who has custodial rights is actively exercising them. ${ }^{51}$ This exception places the burden on the abductor to prove that the parent seeking the return of the child was not exercising his or her custodial rights. ${ }^{52}$ Therefore, little is required in order for the applicant to establish that he or she was exercising custody rights before the abduction..$^{53}$

\section{Settled Into New Environment}

The exception regarding a child already being settled in his or her new environment can be found under Article $12 .{ }^{54}$ This exception allows a Contracting State to refuse to order the return of a child. ${ }^{55}$ The Hague Convention is concerned with the issue of a child who becomes familiar with his or her new surroundings and is then uprooted again and ordered to be returned..$^{56}$ By allowing this exception, the Hague Convention is attempting to enforce one of the goals of the Convention, which is the prompt return of the child to his or her habitual residence. ${ }^{57}$ The more time the return takes, the more settled the child will be into his or her new environment; therefore, the less likely the goals of the Convention are being preserved. ${ }^{58}$

\section{Human Rights and Fundamental Freedom}

Another exception, set forth in Article 20 of the Hague Convention, has rarely been used. ${ }^{59}$ This exception permits a Contracting State to refuse to return

51. Kenworthy, supra note 22, at 336.

52. Id.

53. Id. Article 8(c) explains that the applicant must state "the grounds on which the applicant's claim for return of the child is based." Hague Convention, supra note 9, at 1502. If the applicant fulfills this informal requirement it usually proves to be enough to indicate proper exercise of custodial rights. See Lynda R. Herring, Comment, Taking Away the Pawns: International Parental Abduction \& the Hague Convention, 20 N.C. J. INT'L L. \& Com. Reg. 137, 160-61 (1994).

54. Hague Convention, supra note 9, at 1502. Article 12 states "the judicial or administrative authority... shall also order the return of the child, unless it is demonstrated that the child is now settled in its new environment."

55. Id.

56. Kenworthy, supra note 22, at 336.

57. Lowe, supra note 1 , at 3.

58. Kenworthy, supra note 22, at 336.

59. See Herring, supra note 53, at 171 (citation omitted) (stating that as of 1994, there had not been a single case defining the Article 20 exception). 
child if the return "would not be permitted by the fundamental principles of the requested State relating to the protection of human rights and fundamental freedoms." ${ }^{\text {"60 }}$ Article 20 addresses the drafters' concern with the forum State's public policy, because this Article allows the forum State to apply its particular policies instead of referring "to international agreements dealing with human rights and fundamental freedoms." ${ }^{\text {"6l }}$ Courts, however, are to use judicial restraint when applying this exception so as not to undermine the purpose of the Hague Convention. ${ }^{62}$ This exception is to be invoked only when the return would "utterly shock the conscience of the Court or offend all notions of due process." ${ }^{63}$ Due to the narrow interpretation of this standard, courts have rejected most arguments claiming an Article 20 violation. ${ }^{64}$

\section{Grave Risk of Harm}

Conversely, the grave risk of harm exception is the defense most commonly used by courts. ${ }^{65}$ This exception allows the court to refuse to return the child if the return poses a "grave risk" of exposing the child to "physical or psychological harm or otherwise place the child in an intolerable situation." ${ }^{66}$ The grave risk exception is supposed to be construed narrowly, as are all of the exceptions, and was "intended to be raised when it was established that the child itself (not the abducting parent) would be placed in an intolerable situation if returned to his/her nation of habitual residence." ${ }^{\text {"I }}$ In order for an "intolerable situation" to exist, it must be determined that the risk involves more than trivial complaints and, further, that the situation must be one that is extreme and compelling in nature. ${ }^{68}$ One cannot

60. Hague Convention, supra note 9, at 1503.

61. Lara Cardin, Comment, The Hague Convention on the Civil Aspects of International Child Abduction as Applied to Non-Signatory Nations: Getting to Square One, 20 Hous. J. INT'L L. 141, 153 (1997) (citation omitted).

62. Id. (citation omitted).

63. Id. (quoting McCall v. McCall, [1995] F.L.C. 92-551).

64. Id. (citations omitted). See also Lisa Nakdai, It's IO P.M., Do You Know Where Your Children Are?: The Hague Convention on the Civil Aspects of International Child Abduction, 40 FAм. Cт. Rev. 251, 255 (2002) (citation omitted) (stating that Finland and the United Kingdom did not include Article 20 in their national legislation).

65 . Kenworthy, supra note 22, at 337 (citation omitted).

66. Hague Convention, supra note 9, art 13(b), at 1502.

67. Kenworthy, supra note 22, at 337.

68. Id. at 338. 
simply claim that the child would be better off staying in the country to which she was taken. Courts usually require a showing that there is a high degree of risk that returning the child will lead to psychological or physical harm. ${ }^{69}$

In allowing this exception, the drafters of the Convention wanted to allow the courts some discretion to recognize the realities of returning a child. ${ }^{70}$ This exception allows the courts to look at the merits of the case, even though this practice is in direct conflict with the goals of the Convention. ${ }^{71}$ Allowing the haven state the opportunity to examine the merits of each case has produced uncertainty in the use and interpretation of the grave risk of harm exception. ${ }^{72}$ Some argue that this exception is only utilized in situations where returning the child "places him/her in danger due to some existent condition, such as war or a recent natural disaster." ${ }^{73}$ However, the courts of the various Contracting States have defined grave risk of harm in strikingly different ways and, in so doing, created significant problems. ${ }^{74}$

Courts construing the grave risk of harm exception have applied it in various ways. ${ }^{75}$ For example, a French court found an "intolerable situation" when asked to return a child to Los Angeles. ${ }^{76}$ The court stated that the polluted environment of Los Angeles posed a danger to the child's health. ${ }^{77}$ An Ireland court found an "intolerable situation" where the father was irresponsible with money and caused the family eviction. ${ }^{78}$ American courts, however, are less likely to find an "intolerable situation" and are therefore, less likely to use the grave risk of harm exception. ${ }^{79}$ In Nunez-Escudero v. Tice-Menley, the court did not find an "intolerable situation" where the abducting mother was abused by the husband and father-inlaw. ${ }^{80}$ Courts in the United States have stated that "although children must be

69. Id.

70. Id.

71. Hoben, supra note 15 , at 276 . By examining the merits of the case, the "[Convention]'s objective of ensuring that the rights of custody under the law of one Contracting State are respected in the other Contracting state" is defeated. Id.

72. See id.

73. Kenworthy, supra note 22, at 339 (citing Linda R. Herring, Taking Away the Pawns: International Parental Abduction \& the Hague Convention, 20 N.C. J INT'L L. \& Com. Reg. 137, 148 (1994)).

74. Hoben, supra note 15, at 281, 283.

75. See id.

76. Id.

77. Id.

78. Id. (citing PF v. MF, [1992] 2 Ir. S.C. 390).

79. See id.

80. Id. at 281-82 (citing Nunez-Escudero v. Tice-Menley, 58 F.3d 374, 377 (8th Cir. 1995)). 
safeguarded from a 'grave risk' of harm, other options for the children's protection must be considered beyond allowing the children to stay with the abducting parent." ${ }^{.81}$ Clearly, this narrow interpretation taken by American courts is consistent with the intent of the Convention. ${ }^{82}$ This wide disparity of interpretation is problematic in that it "undermines the effectiveness of the Convention and prevents the Convention from successfully combating the problem of international parental kidnapping. ${ }^{" 83}$ By allowing the courts to exercise great discretion in interpreting the Convention, the Convention is utilizing a state-centered approach. In order for the goals of the Convention to be effective, it is necessary to move away from a state-centered approach and toward a transnational approach by adopting a universal interpretation of this exception. ${ }^{84}$

\section{Child's Objection}

The last exception to the application of the Hague Convention, which has also been interpreted in various ways by the courts in different countries, applies when the child objects to being returned. ${ }^{85}$ When the child is old enough and mature enough to contest being returned, a court may refuse to order the return of the child. ${ }^{86}$ This exception was provided by the drafters because they knew situations would arise where it should be found that the Convention is inapplicable to a particular child otherwise subject to it. ${ }^{87}$ Thus, the drafters reluctantly de-

81. Id. at 282 (citing Blondin v. Dubois, 238 F.3d 153 (2d Cir. 2001)). The mother in this case wanted to invoke the "grave risk" of harm exception in order to prevent the return of the child to the abusive father in France. Id. The Court stated that under the 13(b) exception, the Court must take into account "any ameliorative measures that can reduce the risk to the children, while still allowing the custody determination to take place in the home State." Id.

82. Id. at 283 .

83. Id.

84. Id. at 283. See also Lowe, supra note 1, at 12. The goals of the Convention are to return the child to their habitual residence promptly, thus, recommending that 13 (b) be applied narrowly and to utilize this exception only when there is no other alternative. Id. Also, "where a return order is made despite domestic violence, abuse, and other severe family law matters in the child's habitual place of residence, the Central Authorities should assist in ensuring that these matters are properly forwarded to the appropriate child welfare agencies and the court." Id. at 13.

85. Nakdai, supra note 64 , at 255.

86. Kenworthy, supra note 22, at 339. See Hague Convention, supra note 9, at 1502 (stating " $t \mathrm{t}] \mathrm{he}$ judicial or administrative authority may also refuse to order the return of the child if it finds that the child objects to being returned and has attained an age and degree of maturity at which it is appropriate to take account of its views.").

87. Kenworthy, supra note 22, at 340. 
cided to allow the courts some discretion by permitting them to consider the views of the child. ${ }^{88}$ In applying this exception, a court must consider both whether or not the child has objected and whether the child is mature enough or old enough to allow his/her objection to be considered. ${ }^{89}$ The drafters did not provide a specific age or objective assessment criteria for determining maturity, thus, the application of this exception has been arbitrary. ${ }^{90}$ There have been cases stating that " nine, ten, and twelve year-olds are not of sufficient age in order to merit consideration of their views... while conversely, there have been cases holding that eleven-, twelve-, and thirteen-year-old children are of sufficient age." ${ }^{11}$ The concern with this exception, similar to the grave risk of harm exception, is the potential for abuse of judicial discretion permitted by the Convention's state-centered approach. ${ }^{92}$

Because of inconsistent judicial interpretations, the Hague Convention exceptions create effectiveness problems in terms of serving the purpose of the Convention - the prompt return of the child to the child's habitual residence. ${ }^{93}$ Thus, in order to make the Hague Convention more effective, it is necessary to consider aspects of the Convention on the Rights of the Child, which takes a transnational and global approach to the problem of child abduction.

\section{The Convention on the Rights of the Child}

The Convention on the Rights of Children is the most universally accepted human rights instrument in history. ${ }^{94}$ In 1993, the World Conference on Human Rights set the end of 1995 as a target for the universal ratification of the Convention on the Rights of the Child. By the last day of that year, 185 States had ratified

88. Id.

89. Id.

90. Id.

91. Id. at 341 (citing Sheikh v. Cahill, 546 N.Y.S.2d 517 (N.Y. Sup. Ct. 1989) (holding that a nine year-old fails to be of sufficient age). But cf. Nakdai, supra note 64, at 255 (stating "a nine-year-old girl was found mature enough to make an objection when the court found that her mental age was that of a twelve-year-old" and that an eleven year-old-boy was able to stay in Scotland upon his desire). Lowe, supra note 1 , at 12 (stating that one refusal of return was based on the objections of a four-year-old).

92. Kenworthy, supra note 22, at 341.

93. Lowe, supra note 1 , at 3 .

94. UNICEF, supra note 18. 
the Convention, making it the most widely and rapidly ratified human rights treaty in history. As of mid-2000, only two States had not yet ratified. ${ }^{95}$ The Convention incorporates the full range of human rights for children: civil, political, social, economic, and cultural. ${ }^{96}$ This Convention "empowers the child to develop physically, morally, psychologically, spiritually and socially, to his or her fullest potential." ${ }^{17}$ The drafters of this universally accepted human rights instrument were selected from every region of the world in an effort "to ensure that all cultures, major religions and legal systems were represented in the drafting process." 98

The Convention on the Rights of the Child states that children are defined as "all human beings under the age of 18 , unless the relevant national laws recognize an earlier age of majority." 99 If a country is going to substitute an earlier age, the Convention makes it clear that the country must base this age substitution on the Convention's guiding principles. ${ }^{100}$ The Convention's four guiding principles ${ }^{101}$ are: non-discrimination, ${ }^{102}$ best interest of the child, ${ }^{103}$ survival and development, ${ }^{104}$ and participation. ${ }^{105}$ Age is seen as an important factor when attempting to uphold the principles of the Convention.

95. Id. at http:/www.unicef.org/crc/faq/htm. The two states that have yet to ratify are the United States and Somalia. Currently Somalia is unable to proceed to ratification because it has no recognized government. The United States has signed the Convention, signaling its "intention to ratify — but has yet to do so." Id.

96. Id.

97. Rebeca Rios-Kohn, The Convention on the Rights of the Child: Progress and Challenges, 5 Geo. J. Fighting Poverty 139, 142 (1998).

98. Id. (stating that as a result of using diverse drafters the Convention "represents minimum legal standards and ethical standards agreed to and respected by all sectors of the international community").

99. UNICEF, supra note 18; Convention on the Rights of the Child, supra note 17. Article 1 states "[f]or the purposes of the present Convention, a child means every human being below the age of eighteen years unless, under the law applicable to the child, majority is attained earlier." Convention on the Rights of the Child, supra note 17, at 1459.

100. UNICEF, supra note 18.

101. Id.

102. Convention on the Rights of the Child, supra note 17, at 1459.

103. Id.

104. Id. at 1460.

105. Id. at 1461 . 


\section{A. Non-Discrimination}

The non-discrimination principle of the Convention on the Rights of the Child "obligates States to respect and ensure the rights of each child within their jurisdictions, with no discrimination." 106 Article 2 of the Convention was drafted in order to create the broadest possible protection for children. ${ }^{107}$ The States each carry the burden of taking necessary measures to provide the rights of the Convention to all children within each State's jurisdiction. ${ }^{108}$ Therefore, all States "must not only refrain from any action that would have a discriminatory effect on some child, but also actively protect children from all forms of discrimination." 109 This fundamental non-discrimination principle of the Convention implies that a child does not have to rely on "his or her legal status in order to enjoy the rights embodied in the Convention." 110 This depicts how the Convention reaches past domestic legal orders, regardless of citizenship, and takes a non-state-centered, transnational approach.

106. Rios-Kohn, supra note 97, at 145. Article 2 of the Convention states:

1. States Parties shall respect and ensure the rights set forth in the present Convention to each child within their jurisdiction without discrimination of any kind, irrespective of the childs or his or her parent's or legal guardian's race, colour, sex, language, religion, political or other opinion, national, ethnic or social origin, property, disability, birth or other status.

2. States Parties shall take all appropriate measures to ensure that the child is protected against all forms of discrimination or punishment on the basis of the status, activities, expressed opinions, or beliefs of the child's parents, legal guardians, or family members.

Convention on the Rights of the Child, supra note 17, at 1459.

107. Rios-Kohn, supra note 97, at 145.

108. Id. at $145,146$.

109. Id. at 146.

110. Id. (stating that "the rights therein may be enjoyed by refugee children, children of illegal immigrants, and children who are considered stateless"). 


\section{B. Best Interest of the Child}

The second fundamental principle of the Convention, the best interest of the child, is discussed in Article $3 .{ }^{111}$ For every situation that effects the child, all "possible solutions must be considered and due weight given to the child's best interests." 112 This approach must be used in all situations, "from direct interventions by States in their jurisdictions to the private context of family life, where States may intervene indirectly-through local authorities, for example-to ensure and protect children's rights." 113 Therefore, this principle should be applied when administrative authorities dictate budgets and policies, when private institutions take action regarding children, and when parents make decisions about raising their children. ${ }^{114}$ Broad application of the best interest of the child standard should create sensitivity to the rights and needs of children. ${ }^{115}$ Yet, "this does not guarantee that a child's interest will always prevail; it only guarantees that the child's interest will be fully considered and given due weight in relation to competing interests." 116 This approach promotes "the recognition of the child as possessor of certain rights which entitles him/her to consideration of any interests that may be affected." 17

111. Id. at 145. Article 3 states:

1. In all actions concerning children, whether undertaken by public or private social welfare institutions, courts of law, administrative authorities or legislative bodies, the best interests of the child shall be a primary consideration.

2. States Parties undertake to ensure the child such protection and care as is necessary for his or her well-being, taking into account the rights and duties of his or her parents, legal guardians, or other individuals legally responsible for him or her, and, to this end, shall take all appropriate legislative and administrative measures.

3. States Parties shall ensure that the institutions, services and facilities responsible for the care or protection of children shall conform with the standards established by competent authorities, particularly in the areas of safety, health, in the number and suitability of their staff, as well as competent supervision.

Convention on the Rights of the Child, supra note 17, at 1459.

112. UNICEF, supra note 18 , at http://www.unicef.org/crc/bg005.htm.

113. Id.

114. Rios-Kohn, supra note 97, at 144; see also generally UNICEF, supra note 18.

115. Rios-Kohn, supra note 97, at 144.

116. Id.

117. Kenworthy, supra note 22, at 345. 


\section{Survival and Development}

The survival and development principle of the Convention also discusses the rights of the child. ${ }^{118}$ This principle, found in Article 3 of the Convention, addresses the child's right to life, survival, and development. ${ }^{119}$ Thus, "States Parties must recognize this right as inherent to every child and commit to acting in a way that will ensure and respect this right." ${ }^{120}$ In order to recognize these rights, States have to adopt measures which safeguard life and must not take any actions that "intentionally take life away." ${ }^{21}$ Examples of these measures include actions to "increase life expectancy and to lower infant and child mortality, as well as prohibitions on the death penalty; extralegal, arbitrary or summary executions; and situations of enforced disappearance." ${ }^{122}$ This principle stands for the promotion of human dignity, in that States "should fully ensure the right to an adequate standard of living, including the right to housing, nutrition and the highest attainable standards of health." ${ }^{123}$ These rights are to be ensured "'to the maximum extent possible' - they must do their utmost to give the highest priority to actions undertaken in this regard." 124

The survival and development principle is not limited to a physical perspective. ${ }^{125}$ It also "emphasizes the need to ensure full and harmonious development of the child, including at the spiritual, moral and social levels, where education will play a key role." ${ }^{26}$ In order to promote this principle, States must assume deeper obligations of "ensuring that children will be able to develop talents and abilities to their fullest porential, that children will be prepared for a responsible life in a free society, and that they will feel solidarity with the world they live in." ${ }^{227}$ By promoting such ends as the development of talents, education, and liv-

118. See UNICEF, supra note 18.

119. See id. Article 6 states: "1. States Parties recognize that every child has the inherent right to life. 2. States Parties shall ensure to the maximum extent possible the survival and development of the child." Convention on the Rights of the Child, supra note 17, at 1460.

120. UNICEF, supra note 18 , at http://www.unicef.org/crc/bg006.htm.

121. Id.

122. Id.

123. Id.

124. Id.

125. Id.

126. Id.

127. Id. 
ing in a free society, the Convention attempts to preserve traditionalist structures that are aimed at promoting the human rights of the child regardless of the domestic law at issue. Again, this Convention is utilizing a transnational and global approach, whereas the Hague Convention uses a state-centered approach.

\section{Participation}

Participation, the last guiding principle of the Convention, reaffirms that children are individuals "who have the right to express their views in all matters affecting them and requires that those views be heard and given due weight in accordance with the child's age and maturity." 128 This principle recognizes that children have the potential to enrich the decision-making process. ${ }^{129} \mathrm{In}$ each and every matter concerning a child, the child's right to participate must be considered. ${ }^{130}$ This right "stands on its own; it requires a clear commitment and effective actions to become a living reality and therefore is much more than a simple strategy." 131 The right to participate is "an additional dimension to the universally recognized freedom of expression, implying the right of the child to be heard and to have his or her views or opinions taken into account." 132

The four guiding principles, identified as the "soul of the treaty," are essential in order to understand the spirit of the Convention. ${ }^{133}$ This Convention brought together the rights of children in one instrument and spelled out the rights to be granted to children everywhere, "regardless of where born or to

128. Id. at http://www.unicef.org/crc/bg007.htm. Article 12 states:

1. States Parties shall assure to the child who is capable of forming his or her own views the right to express those views freely in all matters affecting the child, the views of the child being given due weight in accordance with the age and maturity of the child.

2. For this purpose, the child shall in particular be provided the opportunity to be heard in any judicial and administrative proceedings affecting the child, either directly, or through a representative or an appropriate body, in a manner consistent with the procedural rules of national law.

Convention on the Rights of the Child, supra note 17, at 1461.

129. UNICEF, supra note 18 , at http://www.unicef.org/crc/bg008.htm.

130. Id.

131. Id.

132. Id.

133. Rios-Kohn, supra note 97 , at 143. 
whom, regardless of sex, religion, or social origin." 134 The principles and procedures of this Convention differ in many ways from those of the Hague Convention. The differences between the two Conventions derive from the historical, state-centered approach of the Hague Convention, while the Convention on the Rights of the Child employs a transnational, global approach. These differences must be examined in order to determine how to improve the Hague Convention and in effect, better protect children from international abductions.

\section{Resolving the Discrepancies Between the Hague Convention and the Convention on the Rights of the Child In Order to Better Protect the Interest of the Child}

The Hague Convention should adopt several principles and standards set forth in the Convention on the Rights of the Child in order to become more effective in preventing and discouraging international child abductions. The principles that need to be adopted from the Convention on the Rights of the Child include the age requirement, the concept of the best interest of the child, in relation to the grave risk of harm exception under the Hague Convention, and the right of participation for the child, in relation to the child objecting exception. If these principles are taken from the Convention on the Rights of the Child and are adopted and implemented by the Hague Convention, the effectiveness of the Hague Convention would greatly increase. By adopting these principles, the Hague Convention would not only be more effective in preventing international child abductions, but it would also be promoting and protecting the rights of children. Adopting these principles would allow the Hague Convention to reach its greatest potential, as both a human rights document and an effective means of deterring international child abductions.

\section{A. Age}

The first principle which the Hague Convention should adopt from the Convention on the Rights of the Child is the maximum age at which the Convention applies. The Hague Convention only applies when the child is under the age of sixteen. ${ }^{135}$ Yet, the Convention on the Rights of the Child defines a child

134. UNICEF, supra note 18, at http://unicef.org/crc/convention.htm.

135. Hague Convention, supra note 9 , at 1501. 
as anyone under the age of eighteen. ${ }^{136}$ Instead of using sixteen years as the age when the Hague Convention is no longer applicable, the Hague Convention should employ the age of eighteen years instead. Indeed, the sixteen year-old age provision was not greatly disputed under the Hague Convention. ${ }^{137}$ This age was selected "as the crucial age for purposes of the Hague Convention, largely because it was thought that a person over the age of sixteen possessed a strong enough will to mount a successful challenge to the will of his or her parents or any nation's administrative authorities." 138

Yet, the prevailing view in most countries is that eighteen is the age of maturity. In the United States, the age of eighteen "marks the age of maturity,"139 the age when an individual is able to vote and enlist in the army. It has been determined by society that when one is "under age 18, one's physical, mental, emotional, and social growth is still in the formative stage; not yet fully mature."140 Thus, expanding the age provision would bring the Hague Convention more in line with societal views. ${ }^{141}$ The impact of this change would be more theoretical than practical and is "unlikely to reduce substantially the number of international parental abductions, as children between the ages of 16 and 18 generally cannot be taken or kept anywhere without at least their implicit consent." 142 However, this change would promote consistency, ${ }^{143}$ dissuading a state-centered approach, while promoting a transnational, global approach. Therefore, the Hague Convention should apply to children up to the age of eighteen instead of sixteen.

\section{B. Best Interest of the Child and Grave Risk of Harm}

The second provision that should be changed in the Hague Convention relates to the grave risk of harm exception under $13(\mathrm{~b}) .{ }^{144}$ The grave risk of harm

136. Convention on the Rights of the Child, supra note 17, at 1448.

137. See Passanante, supra note 6, at 696.

138. Id.

139. Id.

140. Susan Kramer, Should Youth Under Age 18 Be Tried As Adults in Criminal Court?, available at http://www.powertoshare.com/forums/social/posts/82.html (last modified Sept. 21, 2002).

141. See Passanante, supra note 6 , at 696 (stating that expanding the age provision would bring the Convention more in line with federal laws in the United States).

142. Id.

143. See id.

144. Hague Convention, supra note 9 , at 1502. 
exception is only supposed to be used when "there is a grave risk that his or her return would expose the child to physical or psychological harm or otherwise place the child in an intolerable situation." 145 This exception fails to take into account the best interest of the child and the "precise language of this exception indicates the narrow scope the drafters intended it to have." 146 The Legal Analysis of the Hague Convention stated that the 13(b) exception "was not intended to be used ... as a vehicle to litigate the child's best interests." ${ }^{147}$ Yet, the grave risk of harm exception should take into account the best interest of the child. ${ }^{148}$

The emphasis of the Convention on the Rights of the Child is "promoting the best interest of the child in every situation that could potentially affect him or her." ${ }^{149}$ This notion should be incorporated into the Hague Convention's grave risk of harm exception in Article 13(b). By taking into account the principle of the best interest of the child when determining if there is a grave risk of harm involved in returning the child, the negative, state-centered approach of the Hague Convention can be overcome by the transnational, global standards of the Convention on the Rights of the Child. Thus, allowing the strong human rights aspects of the Convention on the Rights of the Child to enumerate and protect the rights of children.

\section{Participation Rights and Child Objecting}

The last amendment which the Hague Convention should adopt in order for this Convention to better promote the rights of the child relates to the child objecting exception. Under Article 13 of the Hague Convention, the child is able to voice his or her opinion on whether or not he or she wants to be returned. ${ }^{150}$ This excep-

145. Sharon Nelson, Turning our Backs on the Children: Implications of Recent Decisions Regarding the Hague Convention on International Child Abduction, 2001 U. ILL. L. Rev. 669, 677 (2001); Hague Convention, supra note 9, at 1502.

146. Mark Dorosin, You Must Go Home Again: Friedrich v. Friedrich, The Hague Convention and The International Child Abduction Remedies Act, 18 N.C.J. INT'L L. \& Coм. Reg. 743, 751 (1993).

147. Id. at 751 (citing Legal Analysis of the Hague Convention on the Civil Aspects of International Child Abduction, 51 Fed. Reg. 10, 503-06 (1986)).

148. See Nelson, supra note 145, at 693 (arguing that the grave risk of harm exception should be expanded so that it includes psychological abuse because "even if the child is not being beaten [that] does not mean he is not being harmed").

149. Finan, supra note 19, at 1032. See Convention on the Rights of the Child, supra note 17, at 1459.

150. Hague Convention, supra note 9 , at 1501. 
tion "represents a compromise of two significant competing interests-the desire to expand the scope and application of the Convention versus the situation of children under sixteen who have the right to choose their own place of residence."151 However, "the availability of the Child's Objection defense constitutes an essential feature of the Convention and manifests unique significance to society's most cherished asset: children." "152 Thus, this exception should incorporate the right of participation as provided under the Convention on the Rights of the Child.

The right to participation is one of the four principles of the Convention on the Rights of the Child. ${ }^{153}$ This right recognizes the importance of allowing the child "the opportunity to be heard in any judicial and administrative proceedings affecting the child, either directly or through a representative." 154 By having the Hague Convention adopt this principle, all children regardless of age or maturity would be allowed the right and opportunity to be heard in proceedings to determine whether the child should be returned. A strict interpretation of this exception is necessary in order to preserve the aspirations of the Hague Convention. It must be reaffirmed, however, "that children are full-fledged persons who have the right to express their views in all matters affecting them and... that those views be heard and given due weight in accordance with the child's age and maturity." 155 Thus, the Hague Convention's objecting child exception should incorporate the participation rights established by the Convention on the Rights of the Child.

\section{Conclusion}

In order to better protect and promote the rights of children, the Hague Convention's state-centered approach should be tempered by adopting some of the principles which the Convention on the Rights of the Child created through the use of a transnational approach. International child abductions must be prevented, discouraged, and remedied. If the Hague Convention adopts these

151. Rania Nanos, The Views of a Child: Emerging Interpretation and Significance of the Child's $O b$ jection Defense Under the Hague Child Abduction Convention, 22 Brook. J. INT'L L. 437, 443-44 (1996).

152. Id. at 465.

153. See UNICEF, supra note 18, at http://www.unicef.org/crc/bg007.htm.

154. Convention on the Rights of the Child, supra note 17, at 1501.

155. UNICEF, supra note 18 , at http://www.unicef.org/crc/bg007.htm. 
transnational and global principles from the Convention on the Rights of the Child, it will more effectively remedy international child abductions and serve as a human rights document. This would then enable the Hague Convention to reach its greatest potential both as a means of discouraging and remedying international child abductions and as a human rights document. 